\title{
GREEN TOURISM MARKETING STRATEGY IN BANTIMURUNG SOUTH SULAWESI
}

\author{
$\operatorname{Hikmah}^{(1)}$, Nurdin ${ }^{(2)}$ \\ ${ }^{1}$ Student of Hasanuddin University, Indonesia, hikmahnurdin77@gmail.com \\ ${ }^{2}$ STIPAR Tamalatea Makassar, Jl. Perintis Kemerdekaan KM 12 Makassar, nunostipar@gmail.com
}

\begin{abstract}
Green Tourism marketing strategy as an important part of tourism business sustainability. The potential of Green Tourism is considered an effective tool for sustainable development and is the reason for developing countries to use this concept in economic and conservation development strategies. The research design used is a combination of qualitative and quantitative. Qualitative data obtained from interviews with respondents to obtain stakeholder perceptions while quantitative obtained through the process of weighting and rating of the facts internal and external by the respondent. The result of internal and external factor analysis become a reference in the formulation of the marketing strategy of green tourism program at Bantimurung tourist destination in South Sulawesi. The research used several methods, such as IFAS Matrix Analysis and EFAS which will produce a strategy, next SWOT analysis which is assisted with SWOT diagrams and matrices that will produce an alternative strategy. The result of research from internal and external factor analysis which is described through the strength of internal strategic factor (score 2,13) and opportunity from external strategy factor (score 2,28) indicate that green tourism program in Bantimurung has good strength to compete with a competitor. The marketing position of the Green Tourism program in Bantimurung is currently in a "Growing and Developing" position so that the strategy that must be applied is market penetration through promotion and publicity enhancement, market development strategy through cooperation with travel agent, and product development strategy by maintaining price but offering quality Products that are more applicable to tourist.
\end{abstract}

Keywords: strategy; marketing; green tourism 


\section{INTRODUCTION}

In a marketing perspective, the primary goal of marketing is the creation of value for consumers (tourists). The formulation and implementation of the strategy must always be consumer-oriented (consumer oriented), the understanding of the tourists should be done as well as possible. Community grouping or market segmentation strategy, the creation of a positioning position is also done to manage and serve the group of tourist community. Stages of marketing development in the strategic level should be a unity of the segmentation stage, targeting market positioning and branding and marketing mix (Hasan, 2010).

A successful marketing strategy must be developed based on two main points. First, the marketing strategy must be built from five tourism variables, namely; (1) destination location development, (2) time, (3) accessibility, (4) tourism product portfolio, (5) education and socialization for all stakeholders. Second, the marketing strategy should be built on the awareness that tourism provides a number of benefits primarily; (1) ensuring the sustainability of tourism destinations, (2) economic benefits are highly dependent on the well-maintained and well-preserved environment appeal, (3) avoid or reduce unnecessary investment and investment expenses as a result of environmental degradation, (4) meet the expectations of tourists who have a higher awareness of environmental issues, (5) make the environment as a tourism competitiveness and (6) the realization of the environment tourism business environment that benefits all parties (Hasan, 2015).

Green tourism as an important part of tourism business sustainability. The potential of green tourism is regarded as an effective tool for sustainable development and hence the reason for developing countries to use this concept in economic and conservation development strategies. In the business context, green tourism is an alternative tourism, involving visits to natural areas to learn or to implement a range of environmentally friendly activities that have a positive contribution to the local economy and social community. Its main focus is on finding experiences and learning about nature, its flora, fauna and its habitat as well as cultural artifacts of a particular region. If the activities of green tourism 
are done not in accordance with the objectives, the principles and characteristics will cause an environmental disturbance, economic and socio-cultural, occur over intensification, especially ecosystem sensitivity factors of natural and cultural areas. Therefore, in order to the sustainability of green tourism, marketers/companies need to know the environmental, social and economic impacts of green tourism activities and to consider the effects during the planning.

One of the most important dimensions of green tourism success is the community-based management approach. The form of tourism is based on the premise that people living around existing resources are the ones most suited to protect it. Tourism activities and businesses developed and operated by local community members based on their approval and support. The use of local people's knowledge is easier for local people to build a tourism industry whose work is influenced by the responsibility of environmental use for tourism sites (Roxona, 2012).

For the achievement of green tourism, the researcher will see how the supporting facilities of Green Tourism program implementation, how to formulate the right marketing strategy to develop Green Tourism program and how to formulate alternative strategies and marketing programs to promote Green Tourism program at Bantimurung tourist destination in South Sulawesi.

\section{LITERATURE REVIEW}

\subsection{Tourism Marketing Strategy}

Marketing literature calls marketing strategy is a plan by a company to differentiate itself positively from its competitors, using its relative strengths to better satisfy customer needs in a given environment, which is interpreted as a series of decisions and actions of companies that aims to differentiate themselves from competitors and the sustainability of a competitive advantage based on vision and mission, corporate and environmental resources (Cathy, Killion, Brown, Gross \& Huang, 2012). 


\subsection{Segmentation}

In a community, there is a close personal relationship between members of the community because of the similarity of interest or value. The community can be an online community, an offline community or a hybrid (a combination of both). For example the existing community: Greenpeace, WALHI, Bike to Work, Responsible Travel, national geographic, green lifestyle, UNEP (United Nations Environment Program), Facebook, virtual tourist, green travel WWF (World Wild Foundation) and others (Chandler, James \& Carol, 2002).

\subsubsection{Geographic Segmentation}

This segmentation assumes that proximity (proximity area) plays an important role in decision making. The proximity of the region leads to the similarity of taste and ease of access to the service provider. For foreign tourists, the characteristic of the State is quite strong as a differentiating factor in choosing destinations (Chandler, James \& Carol, 2002). Increased apathy for travelers' self-safety where as many as $83 \%$ of British tourists traveling in a travel package say that dirty beaches and polluted seas are a consideration in choosing destinations. $74 \%$ are affected by criminality, $62 \%$ are influenced by the epidemic level in the destination to be selected. $60 \%$ of German tourists are very concerned about garbage, $51 \%$ are very concerned about noise pollution and $46 \%$ about nature protection in destinations. $59 \%$ of US female tourists place the environment as a product-green product base and they recommend others to back to green and revisit environmentally-concerned companies (Chandler, James \& Carol, 2002);

\subsubsection{Psychographic Segmentation}

In the world of tourism, an important part of this segmentation in relation to satisfaction and loyalty are alocentrics, psychocentrics and midcentrics (Skogland \& Siguaw, 2004). 


\subsubsection{Demographic Segmentation}

This segmentation divides the market into groups based on demographic variables such as age, sex, family size, income, occupation, education, religion, and nationality (Skogland \& Siguaw, 2004).

\subsubsection{Behavior Segmentation}

Segmentation behaviorally classifies travelers based on common knowledge, attitude, level of use, and response to a product (Skogland \& Siguaw, 2004).

\subsubsection{Lifestyle Segmentation}

This segmentation based on lifestyle or VALS (values, activities, and lifestyle) is the most relevant basis for market sharing used in marketing tourism destinations based on sustainable values. 'Green Customer' in general and cultural tourists or tourists visiting natural and geo tourist destinations are the type or type of main target market tourists for destination and tourism products based on sustainable values. Research and trends indicate that these types of tourists are more numerous and the number is growing relatively rapidly (Skogland \& Siguaw, 2004).

\subsection{Targeting}

Once the market segment is identified, then selected the most attractive segment and profitable to be targeted (target market). For example major markets and potential markets (John \& Fache, 2011).

\subsection{Positioning}

The positioning strategy is used to achieve profit differentiation. A successful position has characteristics that distinguish itself from others and is important to consumers (John \& Fache, 2011).

\subsection{Competitor Strenght Analysis}


The sustainability and profitability of the industry are strongly influenced by the company's strength in creating value for their buyers as well as how the ability of that value can be a competitive tool (Porter in Manveer \& Sangeun, 2011).

\subsubsection{Identify the Competitor's Strategy}

The purpose of running a business is to win the competition. Therefore, companies must have a strategy to win the market. Likewise, marketers should monitor their competitors' strategies on a continuous basis, as ingenious competitors always revise their strategy over time (Porter in Manveer \& Sangeun, 2011).

\subsubsection{SWOT Analysis}

SWOT analysis (strength, weakness, opportunity, and threats) is one tool used to identify internal and external issues that affect the ability to market a product. To identify the strengths and weaknesses of the product, the marketer must have to look at issues within the organization that affect the ability to sell the product to the market (Porter in Manveer \& Sangeun, 2011).

\subsubsection{Analysis of competitors' strengths and weaknesses}

In the tourism industry, competition takes place between destinations (national and local) as well as between tourist attractions, such as beaches versus beaches or mountains versus mountains. Competitive advantage will form the point of difference based on the analysis of the elements of industrial competition such as competition threats, substitution product threats, threats of newcomers, the threat of increasing supplier bargaining power and the threat of increased bargaining power of buyers (Porter in Manveer \& Sangeun, 2011).

\subsubsection{Strategy to face competitors}

Competitor reaction analysis becomes an important part in the business of formulating competitor patterns and strategies in seizing existing market segments and how companies are able to make new breakthroughs in order to outperform competitors in this constantly changing market. A number of strategies to deal with competitors that can be considered in; product strategy, 
product planning and product development (Porter in Manveer \& Sangeun, 2011).

\subsection{Green Tourism}

Green tourism is a unique program of the tourism industry focused on improving and maintaining nature through tourism activities. Green tourism means different things to different people (Bhattacarya, Chowdury \& Sarkar, 2011); Philosophy of development of green tourism is natural resource-based tourism has a diversity of definitions (Joshi, 2012).

Table 2.1. Characteristics of Mass Tourism and Green Tourism

\begin{tabular}{|c|c|c|}
\hline Component & Mass tourism & Green Tourism \\
\hline Visitors & Big groups & Small Groups \\
\hline Destinations & Urban-beach & Rural \\
\hline Marketing & General tourism marketing & Green tourism marketing \\
\hline Price & $\begin{array}{l}\text { Average for market } \\
\text { penetration purposes }\end{array}$ & $\begin{array}{l}\text { High price to filter market } \\
\text { selection }\end{array}$ \\
\hline Impact & $\begin{array}{l}\text { The impact on the } \\
\text { environment is high }\end{array}$ & $\begin{array}{l}\text { The impact on the natural } \\
\text { environment is slight/small }\end{array}$ \\
\hline Control & Control / control is higher & $\begin{array}{l}\text { Control is limited due to its } \\
\text { specific market segments }\end{array}$ \\
\hline Management & $\begin{array}{l}\text { Based on macroeconomic } \\
\text { principles }\end{array}$ & $\begin{array}{l}\text { Based on the principles of local } \\
\text { economy }\end{array}$ \\
\hline Relationship & $\begin{array}{l}\text { Anonymous relationships } \\
\text { between visitors and the local } \\
\text { community } \\
\text { General development }\end{array}$ & $\begin{array}{l}\text { Anonymous relationships } \\
\text { between visitors and the local } \\
\text { community }\end{array}$ \\
\hline Orientasi & $\begin{array}{l}\text { Entertainment-oriented } \\
\text { entertainment behavior }\end{array}$ & $\begin{array}{l}\text { Regional development } \\
\text { Training and behavioral } \\
\text { education appropriate to the } \\
\text { natural environment to create } \\
\text { loyalty }\end{array}$ \\
\hline
\end{tabular}

(Source : Dorobantu \& Nistoreanu, 2012)

Sometimes green tourism is interpreted as an outdoor recreation activity that is exotic, isolated in the wilderness or in swamps, sometimes conventional or perhaps modern transportation for an activity focusing on three areas: quality, 
continuity, and benefits (Weaver \& Lawton, 2007); These three focuses should be placed in the context of regional-based green tourism product development planning which is then socialized through the concept of green tourism marketing to reach an increasingly segmented market through product diversification efforts (Boghean, 2006).

\subsection{Green Tourism Sustainability}

The idea of sustainable development notes that economic growth and environmental conservation are not only compatible but must be synergized with each other. The potential for sustainable development is high for every society in economic, social, cultural, ecological and physical constraints (Bhuiyan, Siwar \& Ismail, 2012). Sustainable development is a program to change the process of economic development so as to ensure the basic quality of life for all and at the same time protecting ecosystems and community systems that make life more likely and valuable, characterized by the maintenance of ecological integrity and biodiversity, can meet the basic needs of life human beings such as work, food, energy, water and sanitation. Reviving economic growth and changing the quality of environment-based growth and environmental and economic incorporation should be the basis for decision making (Wall, 2007). The idea of sustainable development is the intergenerational equality in integrating the economic, social and environment by sharing natural resources between people living today with future generations that inhabit the planet through resource conservation efforts (Jaini, Anuar \& Daim, 2012).

\subsection{Impact of Green Tourism}

Tourism can be sustainable if able to meet the needs of tourists and local communities while protecting future opportunities. Green tourism offers benefits to local communities, conservation, development and experience of resourcebased education (Catibog \& Wen, 2008). Green tourism requires a combination of conservation and economics that benefits local people on an ongoing basis. Natural and cultural values form geographical position, microclimate conditions, water availability, natural beauty, local food, history and cultural heritage, traditional music and so on ( $\mathrm{Li}, 2006)$. Green tourism operates in one or more eco-friendly alternatives in the use of economic resources from nature, 
promoting an enhanced appreciation of environmental education for visitors and locals specifically designed to preserve natural resources and contribute in the form of environmental conservation and biodiversity ( Bob, Swart, Maharaj \& Louw, 2008). Planning is also developed in the context of awareness of the environment and water resources that create benefits both in terms of visibility and utilization. The climate features of tourism, directly and indirectly, play an important role in the development of regional tourism. The image, quality, size, and appearance of the destination is an interesting component of green tourism (Fung \& Wong, 2007). The values of traditional commercial products are one of the most significant appeals in the development of green tourism in a region, largely because of the uniqueness of the entire production process which is colored by the management of cultural differences that are mostly done in the traditional way. Green tourism has a potentially serious positive impact on the local community, some bear due to the tendency of green tourists to have a greater interest in nature and culture in the areas they visit than with mass tourist (Goalkeepers, 2011). The design of green tourism aims to make people or travelers always sensitive to the environment including birdwatching, trekking, mountain climbing, learning about flora and fauna combining various activities in nature, opportunities to respect nature and local culture, the chance of relaxation and self-reflection inspired by beauty of the environment (Rahman, 2010). Green tourism encompasses a spectrum of nature-based activities that encourage visitor appreciation and understanding of natural, cultural and cultural heritage into sustainable ecological, economic and social. Therefore, green tourism is accepted as an alternative type of sustainable development (Fadahunsi, 2011).

Green tourism is increasingly hailed as a sustainable development option for rural communities, capable of spurring economic development and environmental protection at the same time. If there is no integrity of environmental, economic and social sustainability, then the activity is not green tourism (Bansal, Kumar, 2011). It is called green tourism if it is able to actively contribute to the preservation of natural and cultural heritage, including local communities in the planning, development and operation of activities as well as contribute to their welfare, appealing to individual visitors as well as small 
organized groups especially related to natural resources and culture as a form of relationship between green tourism and sustainable development (Buchsbaum, 2004). Green tourism criteria should include the sustainability of social, economic, and environmental indicators, meaning economically viable, environmentally and culturally appropriate (Medina, 2005).

\subsection{Integration of Green Marketing Activities}

Strategies, programs and operational greening of tourism companies in one area may not be effectively utilized. A company can make major changes in the production process by positioning itself as an environmental leader in all marketing activities (Polonsky, 2011). Companies are increasingly realizing the benefits of green marketing, although there is often a fine line between doing it for self-interest and for social responsibility reasons. The term greenwashing refers to all industries that adopt green action in order to increase profits. The main purpose of greenwashing is to show consumers that companies take steps and responsibilities to manage ecological footprints (Cherian \& Jacob, 2012).

\section{METHODOLOGY}

\subsection{Research Design}

Based on the background of problems raised in the selected research approach is qualitative and quantitative combined research. Qualitative data obtained from interviews with respondents to obtain a description of stakeholder perceptions, in this case, is the Department of Tourism and other relevant agencies, on the implementation of Green Tourism program. While qualification of quantitative data obtained through the process of weighting and rating of the facts internal and external by the respondent. The results of internal and external facts analysis become a reference in the formulation of the marketing strategy of Green Tourism program at Bantimurung tourist destination in South Sulawesi.

\subsection{Research Location}

This research was conducted in Bantimurung Maros regency, South Sulawesi. The chosen location as a research location based on consideration of the number of local tourists, archipelago and foreign tourists who visit the 
location. Likewise geographical conditions that greatly support the implementation of Green Tourism program.

\subsection{Types and Data Sources}

The type of data used in this study is qualitative data is data in the form of words, sentences, schemes and drawings that can be described in detail and clear to draw conclusions about the potential and opportunities of Green Tourism programs and marketing strategies Bantimurung. Types of quantitative data in the form of figures that include the results of the assessment of program stakeholders and facilitators of Green Tourism program implementers in Bantimurung.

There are two data sources: (1) Primary data source, which is data obtained directly from Bantimurung as the organizer of green tourism program, and Internal section as research subject both from the tourism office, staff and local people working at that location; (2) Secondary data sources, ie data obtained from other sources that are not from the first party.

\subsection{Research Instruments}

To collect this research data, research instrument that will be used is interview guideline (interview guideline) and questionnaire. This interview guide and questionnaire are used to determine the program components. Products (accommodation and service facilities) are both price and quality so that these guidelines can be used to determine the strengths and weaknesses of programs and threats and opportunities so that it can determine what and how appropriate marketing strategies to use in marketing this Green Tourism program.

\subsection{Data Collection Method}

The data collection used several methods, among others: (1) Observation, is a direct observation of the field using an instrument of observation guidance. This method complements the interview method or in other words validates the interview method. So that the data and information obtained to be valid and accurate; (2) In-depth interview is collecting data by direct question and answer based on the demands of interview guidance with the related institution at the time of research. In-depth interview techniques were conducted to obtain data 
not found at the time of observation. Through this interview will be obtained more information in order to be able to answer the issues to be discussed; (3) Documentation, data obtained from various official documents both the government, in this case is the Department of Tourism, as well as from private parties or agencies who became partners in the implementation of this research; (4) Distribution of structured questionnaires to stakeholders to find out the policy strategies taken in the implementation of this program.

\subsection{Data Analysis}

In this research used several analytical methods such as IFAS Matrix Analysis and EFAS that will produce a strategy (General Strategic), then SWOT analysis is assisted with diagrams and SWOT matrices that will generate alternative strategies.

\section{FINDING / DISCUSSION}

\subsection{Matriks IFAS and EFAS}

The analysis is based on various aspects covering various things that closely related to promotion of Green Tourism in Bantimurung. In the following analysis views the internal and external conditions of Green Tourism marketing in Bantimurung based on the opinions of respondents for both weight and rating as written as attached in Table 4.1 and Table 4.2 data processed from the results of research 2017.

Tabel 4.1 Internal Factor Analysis Summary (IFAS)

\begin{tabular}{lll}
\hline No & Internal Strategy Factor Strength & Score \\
\hline 1 & $\begin{array}{l}\text { Support from the government through the existence of the Ministry of } \\
\text { Forestry, Directorate General PHKA, Bantimurung Bulusaraung } \\
\text { National Park Hall, as well as existing devices under it. }\end{array}$ & \\
2 & $\begin{array}{l}\text { Regulatory instruments and GOl policies related to the conservation } \\
\text { of biological natural resources and their ecosystems and the }\end{array}$ & 0,42 \\
3 & $\begin{array}{l}\text { environment. } \\
\text { Availability of human resources. }\end{array}$ & 0,45 \\
& $\begin{array}{l}\text { It has a complete natural tourist attraction, such as various types of } \\
\text { butterflies, waterfalls, rivers to play, caves, landscape mountains and }\end{array}$ & \\
5 & $\begin{array}{l}\text { natural forests. } \\
\text { It has local cultural attractions, crafts, and local food }\end{array}$ & 0,08 \\
Easy accessibility from Makassar city, Maros, Bone, and Hasanuddin & 0,24 \\
\hline
\end{tabular}




\begin{tabular}{|c|c|c|}
\hline \multicolumn{3}{|c|}{ International Airport. } \\
\hline & Total Score & 2,13 \\
\hline No & External Strategy Factor Weakness & Score \\
\hline 1 & $\begin{array}{l}\text { Weak participation and community institutions, especially the } \\
\text { community around the area. }\end{array}$ & 0,41 \\
\hline 2 & The bureaucratic system that causes high economic costs. & 0,38 \\
\hline 3 & Still lack science and technology support & 0,29 \\
\hline 4 & $\begin{array}{l}\text { Weak coordination, integration, and synchronization between different } \\
\text { sectors }\end{array}$ & 0,05 \\
\hline 5 & $\begin{array}{l}\text { Lack of human resources, in implementing the conservation and } \\
\text { protection of the region. }\end{array}$ & 0,19 \\
\hline 6 & There is still a lot of tourism potential in unexplored areas & 0,13 \\
\hline & Total Score & 1,45 \\
\hline & TOTAL & 3,58 \\
\hline
\end{tabular}

\section{Tabel 4.2 External Factor Analysis Summary}

\begin{tabular}{|c|c|c|}
\hline No & External Strategy Factors Opportunities & Score \\
\hline 1 & $\begin{array}{l}\text { The commitment of policymakers at the national and regional levels } \\
\text { towards the conservation of natural resources and the environment. }\end{array}$ & 0,42 \\
\hline 2 & $\begin{array}{l}\text { International community commitment and support to the environment } \\
\text { and conservation of natural resources. }\end{array}$ & 0,71 \\
\hline 3 & $\begin{array}{l}\text { Support of community institutions at the local level on the } \\
\text { conservation of natural resources and the environment. }\end{array}$ & 0,12 \\
\hline 4 & $\begin{array}{l}\text { The potential of biodiversity and its unique, rare, and high-value } \\
\text { ecosystems and the high interest of local and foreign communities. }\end{array}$ & 0,37 \\
\hline 5 & $\begin{array}{l}\text { Investment opportunities to conservation areas in the framework of } \\
\text { the development of nature tourism. }\end{array}$ & 0,44 \\
\hline \multirow[t]{2}{*}{6} & The high interest of tourists to see the animals contained this area & 0,16 \\
\hline & Total Score & 2,28 \\
\hline No & External Strategy Factors Threats & Score \\
\hline 1 & $\begin{array}{l}\text { High levels of vulnerability, both from illegal logging activities and } \\
\text { illegal timber trade, encroachment, forest fires and unauthorized }\end{array}$ & 0,16 \\
\hline 2 & mining activities & 0,16 \\
\hline 3 & The low level of community education around the area & 0,16 \\
\hline 4 & $\begin{array}{l}\text { The condition of the people's economy is still heavily dependent on } \\
\text { the availability of natural resources within the region }\end{array}$ & 0,22 \\
\hline \multirow[t]{4}{*}{5} & Land needs are very high & 0,42 \\
\hline & $\begin{array}{l}\text { Investment policies within conservation areas are not attractive to } \\
\text { investors }\end{array}$ & \\
\hline & Total Score & 1,12 \\
\hline & Total & 3,40 \\
\hline
\end{tabular}


From the calculation of the total score of each internal factor item (Table 4.1) and external factors (Table 4.2), it can be labeled as Table 4.3.

Table 4.3 Internal and external factor measurement results

\begin{tabular}{llll}
\hline Internal Faktor & Score & External Factor & Score \\
\hline Strenght & 2,13 & Opportunity & 2,28 \\
Weakness & 1,45 & Threats & 1,12 \\
Total & 3,58 & Total & 3,40 \\
\hline
\end{tabular}

Source: data processed from the results of research, 2017

To assess the results of the assessment on the company's position internally and externally is done through the following formula:

$$
\text { Interval = Range } / \text { Class }=3 / 4=0.75
$$

Range $=$ highest and lowest difference 4 (very good) -1 (very less) $=3$, whereas Class $=$ The rating type is 4 (very good, good, bad, very less). Thus the assessment interval equals $3 / 4=0.75$. From the formula was obtained criteria assessment results in the following table.

Table 4.4 Criteria Results Analysis

\begin{tabular}{cccc}
\hline Value & Range & Mentions & Result \\
\hline 4 & $3,26-4,00$ & Very Good & Strenght/ Opportunity \\
3 & $3,51-3,25$ & Good & Strenght/ Opportunity \\
2 & $1,76-2,50$ & Less & Weakness/ Threats \\
1 & $1,00-1,75$ & Very Less & Weakness/ Threats \\
\hline
\end{tabular}

Based on Table 4.4 external variables provide an overview of opportunities and threats. Opportunities are in good and excellent value range (2.51 to 4.00) while threats are in the range of less and very less (1.00 to 2.50). While the internal environment provides a picture of the strengths and weaknesses. The term is very well identified very strongly, and well strong (2.51 to 4.00). Less well identified with weak, and very less called very weak. So the criteria are very good and good is the strength while less good and very less said weakness (1.0 to 2.50).

By looking at the results of the measurement of internal and external factors in Table 4.3 it can be said that the total internal score of 3.58 is in the range (3.26 to 4.00 ) which means excellent and external 3.40 is in the range (3.26 
to 4,00$)$ which means very good. Furthermore, the scores are depicted on the IE matrix as presented in Figure 4.1

Figure 4.1 Matrix IE

\begin{tabular}{|c|c|c|c|}
\hline \multicolumn{4}{|c|}{ Total Skor Faktor Internal 3,58 } \\
\hline & Strona & Medium & Weak \\
\hline & $3,0-4,0$ & $3,0-4,0$ & $3,0-4,0$ \\
\hline $\begin{array}{l}\text { Kuat } \\
3,0-4,0 \\
\text { Total } \\
\text { Skor } \\
\text { Faktor } \\
\text { Ekstern } \\
3\end{array}$ & $\begin{array}{l}\text { Grow and Build } \\
\text { (konsentrasi via } \\
\text { integrasi vertical) }\end{array}$ & $\begin{array}{c}\text { Grow and Build } \\
\text { (konsentrasi via } \\
\text { integrasi horizontal) }\end{array}$ & $\begin{array}{l}\text { Maintain and maintain } \\
\text { (grow arround) }\end{array}$ \\
\hline $\begin{array}{l}\text { Medum } \\
2,0-2,9\end{array}$ & $\begin{array}{l}\text { Grow and build } \\
\text { (pause) }\end{array}$ & $\begin{array}{c}\text { Maintain and } \\
\text { maintain ( strategy } \\
\text { has not changed) }\end{array}$ & $\begin{array}{l}\text { Harvest or divestment } \\
\text { (bound or sold out } \\
\text { areas of awareness) }\end{array}$ \\
\hline Lemah & $\begin{array}{c}\text { Maintain and } \\
\text { maintain (diversifikasi } \\
\text { konsentrasi) }\end{array}$ & $\begin{array}{l}\text { Harvest or } \\
\text { divestmen } \\
\text { (diversifikasi } \\
\text { konglomerat) }\end{array}$ & $\begin{array}{l}\text { Harvest or divestmen } \\
\text { (likuidasi) }\end{array}$ \\
\hline
\end{tabular}

From Figure 4.1 it is seen that the marketing position of Green Tourism in Bantimurung is in the position of Growing and Bina. Growing position and Bina is based on the strength of Bantimurung with a score of 2.13 while the weakness in the score value of 1.45 . In fact, the position of this number indicates that the differences in strengths and weaknesses are quite significant. If you see the opportunities that exist, then the score of 2.28 and the threat score 1.12. Opportunities are still there and threats can still be minimized. Internal factors have excellent strengths to compete with competitors and externally show the chance to win the competition. With this condition, Green Tourism in Bantimurung can be developed to a higher level by using the strategy of "Growth and Maintain Strategy" or "Grow and Build" strategy consisting of market penetration strategy, market development strategy, and product development strategy.

Market penetration strategy is done because Bantimurung believes that the existing market targets are the domestic and foreign tourists will continue to grow due to their desire to gain experience, especially the unique culture. This is 
supported by the globalization of information so rapidly that it increases the desire of the tourist special interest to travel to South Sulawesi.

\subsection{Alternative Strategies and Programs- Marketing Programs}

Based on data and information in Table 4.1 and Table 4.2 then with SWOT will be found alternative marketing strategies Green Tourism in Bantimurung that can answer the needs of tourists. Based on the analysis of strategic factors both internal and external which consist of strength factor, weakness, opportunity, and threat on SWOT matrix as presented in Table 4.2. Furthermore, the strategies formulated in Table 4.2. will be translated into programs.

Table 4.2. SWOT Analysis Green Tourism Marketing in Bantimurung

\begin{tabular}{|c|c|c|}
\hline EKSTERNAL & $\begin{array}{l}\text { Strength / } \\
\text { Strength } \\
\text { - The existence of } \\
\text { government } \\
\text { support } \\
\text { - Legislation } \\
\text { Availability of } \\
\text { human resources } \\
\text { - Have complete } \\
\text { attractions such as } \\
\text { waterfalls, } \\
\text { butterflies and more } \\
\text { - Have local cultural } \\
\text { attractions, local } \\
\text { food, and crafts } \\
\text { - Easy accessibility }\end{array}$ & $\begin{array}{l}\text { Weakness / Weakness } \\
\text { - Weak participation and } \\
\text { community institutions } \\
\text { - The bureaucratic system } \\
\text { that causes high economic } \\
\text { costs } \\
\text { - Still weak science and } \\
\text { technology support } \\
\text { - Weak coordination, } \\
\text { integration, and } \\
\text { synchronization between } \\
\text { various sectors } \\
\text { - Lack of human resources in } \\
\text { implementing conservation } \\
\text { and protection of the region } \\
\text { - There are still many } \\
\text { unexplored potentials }\end{array}$ \\
\hline $\begin{array}{l}\text { Opportunities / Opportunities } \\
\text { - Commitment of policymakers at the national } \\
\text { and regional levels } \\
\text { - Community commitment and support } \\
\text { - Community support at the local level } \\
\text { - Potential biodiversity } \\
\text { - Investment opportunities } \\
\text { - The high interest of tourists }\end{array}$ & $\begin{array}{l}\text { S-O Strategy } \\
\text { - Consolidation of } \\
\text { tourist destinations } \\
\text { - Improve product } \\
\text { quality and human } \\
\text { resources }\end{array}$ & $\begin{array}{l}\text { S-O Strategy } \\
\text { - Consolidation of tourist } \\
\text { destinations } \\
\text { - Improve product quality and } \\
\text { human resources }\end{array}$ \\
\hline $\begin{array}{l}\text { Threat / Threat } \\
\text { - High level of vulnerability of the area } \\
\text { - Low level of community education } \\
\text { - The people's economy is still dependent on } \\
\text { the availability of natural resources within the } \\
\text { region } \\
\text { - High land requirements } \\
\text { - Investment policies that are not attractive to } \\
\text { investors }\end{array}$ & $\begin{array}{l}\text { S-T Strategy } \\
\text { - Highlights of } \\
\text { Green Tourism } \\
\text { excellence } \\
\text { - Creation of } \\
\text { security } \\
\text { - Investment } \\
\text { policies that attract } \\
\text { investors }\end{array}$ & $\begin{array}{l}\text { S-T Strategy } \\
\text { - Highlights of Green Tourism } \\
\text { excellence } \\
\text { - Creation of security } \\
\text { - Investment policies that } \\
\text { attract investors }\end{array}$ \\
\hline
\end{tabular}

\section{CONCLUSION / IMPLICATIONS}


The analysis of internal and external factors described through the strength of internal strategic factors (score 2.13) and opportunities from external strategic factors (score 2.28) indicates that Green Tourism in Bantimurung has a good strength to compete with competitors and externally indicate the opportunity to win the competition. Green Tourism's marketing position in Bantimurung is currently in a "Growing and Developing" position so that the strategy to be implemented is market penetration through increased promotion and publicity, market development strategy through cooperation with travel agent, and product development strategy by maintaining price but offering product quality which is more applicable to tourists. Alternative strategies and marketing programs that can be done is by consolidating tourist destinations, improving product quality and human resources, promoting promotion, enhancing cooperative relationships, engaging local people, highlighting program excellence, creating security, pricing products without suffering losses, and consistency of rules and execution.

\section{REFERENCES}

Bhattacarya, Chowdury, Sarkar. 2011. Irresponsible Green Tourism Practices Flanking The Best National Park in India: A Multivariate Analysis. International Business and Economic Research, Vol 19. No 1.pp 19-28

Bhuiyan, Siwar, and Ismail. 2012. The Role Of Green Tourism for Sustainable Development In East Coast Economic Region. International Journal of Sustainable Development, Vol. 3 No. 9, pp 53-67

Bob, Maharj, and Louw. 2008. Nature, People, and Environment: Overview of Selected Issues Alternation, Vol 15 No. 11 pp 71-89

Boghean. 2006. Multi-Model Eco Tourist. Journal Research Tourism, Vol 1 No. 4, pp 34-57

Buchsbaum. 2004. Green Tourism and Sustainable Development. International Tourism Journal. Vol. 11 No 3.

Catibog and Wen. 2008. Sustainable Tourism Planning and Management Model For Protected Natural Areas. Asia Pacific Journal of Tourism Research, Vol 1, No. 3. Pp 41-56 
Chandler, James A, and Carol A. Costello, 2002. A Profile of Visitors at Heritage Tourism Destinations in East Tennessee according to Plog's Lifestyle and Activity Level Preferences Model, Journal of Travel Research, Vol. 41, No. 2

Dolnicar, Sara. 2006 \& Matus. K, 2008. Are Green Tourist A Managerially useful Target Segment. Journal of Hospitality and Leisure Marketing, 17 (3-4)

Dorobantu, and Nistoreanu. 2012. Rural Tourism and Green Tourism: The Main Priorities in Sustainable Development Orientations of Rural Local Communities. Economy Transdisciplinarity Cognition, Vol. 15, No 12, pp 56-66

Fadhanusi, 2011. Application of Geographical Information System (GIS) Technology To Tourism Management. The Pacific Journal of Science and Technology, Vol 1 No. 2, pp 22-34

Fung T. 2007. Green Tourism Planning Using Multiple Criteria Evaluation. GIS Geocarto International. Vol 2 No.2, pp 97-05

Hasan, Ali. 2010. Word of Mouth Marketing. Yogyakarta: Media Pressindo Utama.

Jaini and Daim. 2012. The Practice Of Sustainable Tourism in Green Tourism Sites Among Green Tourism Providers. Asian Social Science Vol. 8 No. 4 pp17-29

John W. Meyer and Fache, Charles W. Franc. 2011. Market Positioning, Differentiation, and Branding, Customer Lead Media

Joshi, R.L. 2012. Green Tourism Planning and Management. Green Tourism Destinations Forestry, Vol. 11. No. 2 pp 10-22

Kiper, T. 2011. The Determination of Nature Walk Routes Regarding Nature Tourism. Journal of Food Agricultural and Environment, Vol 9 No. 3, pp 22-32

Li, W. 2006. Community Decision- Making Participation In Development. Annals of Tourism Research, Vol 3 No. 3, pp 13-21

Medina. 2005. Green Tourism and Certification: Confronting The Principle and Pragmatics of Socially Responsible Tourism. Journal of Sustainable Tourism. Vol 13, No 2, pp 18-29

Porter, Michael on Manveer, K. Mann and Sangeun, Byun. 2011. Assessment of Five Competitive Forces of Apparel Retail Industry. Journal of Technology and Management. Vol. 7 (2) pp 1-14

Rahman. 2010. Application of GIS in Green Tourism Development. Human Geography Focusing in Tourism, Vol 4 No 5, pp 83-79

Roxona, D.M. 2012. Considerations About Green Tourism and Nature-Based tourism -Realities and Perspective. International Journal of Academic Research in Economics and Management Science, Vol 15 No 21, 22-37 
Skogland, I., \& Siguaw, J.D. 2004. Are You Satisfied Tourist Loyal ?. Hotel and Restaurant Quarterly

Wall, G. 2007. Sustainable Development, Sustainable Tourism and Sustainable Livelihoods; International Tourism Biennial. Vol 13, No 7 pp 63-79

Weaver and Lawton. 2007. Twenty Years On: The State of Contemporary Green Tourism. Tourism Management, Vol 28, No 11, 61-79 